\title{
Gambaran Tingkat Kecemasan pada Warga yang Tinggal di Daerah Rawan Longsor di Kelurahan Ranomuut Kota Manado
}

\author{
${ }^{1}$ Nikhita F. A. Mamesah \\ ${ }^{2}$ Hendri Opod \\ ${ }^{2}$ Lydia David
}

\author{
${ }^{1}$ Program Studi Pendidikan Dokter Fakultas Kedokteran Universitas Sam Ratulangi \\ Manado \\ ${ }^{2}$ Bagian Psikologi Fakultas Kedokteran Universitas Sam Ratulangi Manado \\ Email: fnikhita@yahoo.com
}

\begin{abstract}
Anxiety is a normal reaction that helps human to deal with danger or tough situation. Anxious people feel afraid, worry, and have physical changes such as increased blood pressure. This condition can happen especially among people who live in the landslideprone area. They always feel worried and anxious when rain as well as earthquake or any condition that can trigger landslide occurs. This study was aimed to determine the anxiety level among residents living in the landslide prone-area Ranomuut Manado. This was a descriptive study with a cross sectional approach. Samples were obtained by using the purposive sampling technique. Respondents were residents of Ranomuut Lingkungan IV Manado. The anxiety level was measured with Hamilton Anxiety Rating Scale (HAR-S) questionnaire. The results showed that there were 43 respondents who participated in this study; 22 females (51.1\%) and 21 males (48.9\%). The anxiety levels were mild anxiety in 11 respondents $(25.6 \%)$, moderate anxiety in 22 respondents $(51.1 \%)$, severe anxiety in 8 respondents (18.6\%), and no anxiety in 2 respondents (4.7\%). Conclusion: Most residents in landslide prone-area had anxiety, and the most common anxiety was moderate anxiety.
\end{abstract}

Keywords: anxiety, landslide prone-area, Hamilton Anxiety Rating Scale (HAR-S)

\begin{abstract}
Abstrak : Kecemasan adalah reaksi normal yang membantu manusia menghadapi situasi yang berbahaya atau sulit. Kecemasan merupakan suatu perasaan yang sifatnya umum, dimana seseorang merasa ketakutan, memiliki pikiran yang khawatir, dan perubahan fisik seperti tekanan darah yang meningkat. Keadaan ini dapat terjadi khusunya bagi orang yang tinggal di daerah rawan longsor yang akan selalu waspada dan juga merasa cemas disaat hujan, gempa atau hal-hal yang dapat memicu terjadinya longsor. Penelitian ini bertujuan untuk mengetahui gambaran tingkat kecemasan pada warga yang tinggal di daerah rawan longsor di Kelurahan Ranomuut, Kota Manado. Jenis penelitian ialah deskriptif dengan desain potong lintang. Teknik pengambilan sampel menggunakan purposive sampling. Responden penelitian ialah warga Kelurahan Ranomuut Lingkungan IV. Tingkat kecemasan diukur menggunakan kuesioner Hamilton Anxiety Rating Scale (HAR-S). Hasil penelitian mendapatkan bahwa responden yang mengikuti penelitian berjumlah 43 orang, terdiri dari perempuan 22 orang $(51,1 \%)$ dan laki-laki 21 orang $(48,9 \%)$. Tingkat kecemasan yang didapatkan ialah kecemasan ringan sebanyak 11 orang $(25,6 \%)$, kecemasan sedang sebanyak 22 orang $(51,1 \%)$, kecemasan berat sebanyak 8 orang $(18,6 \%)$, dan yang tidak memiliki kecemasan sebanyak 2 orang $(4,7 \%)$.

Simpulan: Sebagian besar masyarakat yang berdiam di daerah rawan longsor mengalami kecemasan, terutama kecemasan sedang.
\end{abstract}

Kata kunci: kecemasan, daerah rawan longsor, Hamilton Anxiety Rating Scale (HAR-S) 
Manusia adalah makhluk hidup ciptaan Tuhan. Semua manusia ingin menjalani hidup dengan penuh kedamaian dan ketenangan tetapi ketenangan ini dapat terancam jika terjadi bencana antara lain bencana alam seperti gempa bumi, tsunami, gunung meletus, banjir, kekeringan, angin topan, dan tanah longsor. ${ }^{1}$ Menurut Nugroho et al, ${ }^{2}$ bencana alam adalah salah satu fenomena yang dapat terjadi setiap saat, dimanapun, dan kapanpun sehingga menimbulkan risiko atau bahaya terhadap kehidupan manusia, baik kerugian harta benda maupun korban jiwa manusia. ${ }^{2}$ Bencana ini dapat menganggu manusia dalam menjalankan aktivitas sehari-hari.

Tanah longsor merupakan salah satu peristiwa traumatik yang dapat mengancam keselamatan manusia. ${ }^{3}$ Tanah longsor lebih sering terjadi pada saat hujan. Tanah longsor bukan hanya memberikan dampak kerusakan bangunan tetapi juga berdampak psikologis bagi masyarakat seperti perasaan cemas, takut, putus asa, depresi, sedih, trauma, dan juga perilaku agresif yang tak bisa dikontrol. Demkian pula bagi masyarakat yang tinggal di daerah rawan longsor. Setiap saat terjadi hujan masyarakat tersebut selalu merasa cemas manakala terjadi longsor. Daerah rawan longsor merupakan daerah atau kawasan yang sering atau berpotensi tinggi mengalami bencana alam longsor.

Kecemasan adalah reaksi normal yang membantu manusia menghadapi situasi yang berbahaya atau sulit. ${ }^{4}$ Ketika dihadapkan dengan pemicu yang berpotensi membahayakan atau mengkhawatirkan, perasaan cemas tidak hanya normal tetapi diperlukan untuk bertahan hidup. ${ }^{5}$ Kecemasan yang berlebih dapat mengganggu konsentrasi orang dalam melakukan aktivitas mereka sehari-hari

Bencana longsor sering melanda Kota Manado khususnya saat musim hujan dan merugikan banyak warga dikarenakan banyak warga Manado yang tinggal di daerah perbukitan yang merupakan daerah rawan longsor. Penelitian ini bertujuan untuk mengetahui gambaran tingkat kecemasan pada warga yang tinggal di daerah rawan longsor di Kelurahan Ranomuut Kota Manado.

\section{METODE PENELITIAN}

Jenis penelitian ini ialah deskriptif dengan desain potog lintang untuk menilai apakah terdapat kecemasan pada warga yang berada di daerah rawan longsor dengan menggunakan data sosiodemografik dan kuesioner Hamiltion Anxiety Rating Scale (HAR-S).

Populasi penelitian ialah warga Kelurahan Ranomuut Lingkungan IV. Teknik sampling yang digunakan ialah purposive sampling. Jumlah sampel yang memenuhi kriteria inklusi ialah 43 responden.

\section{HASIL PENELITIAN}

Berdasarkan hasil penelitian yang dilakukan terhadap 43 responden, didapatkan jenis kelamin perempuan sebanyak 22 orang $(51,1 \%)$ dan laki-laki sebanyak 21 orang $(48,9 \%)$ (Tabel 1$)$.

Tabel 1. Distribusi responden menurut jenis kelamin

\begin{tabular}{ccc}
\hline Jenis kelamin & (n) & \% \\
\hline Laki-laki & 21 & 48,9 \\
Perempuan & 22 & 51,1 \\
Total & 43 & 100 \\
\hline
\end{tabular}

Mayoritas responden yang berpartisipasi dalam penelitian ini pada kategori usia 25-30 tahun sebanyak 9 orang (21\%) dan yang paling sedikit ialah pada usia 51-55 tahun sebanyak 2 orang (4,7\%) (Tabel 2).

Tabel 2. Distribusi responden menurut usia

\begin{tabular}{ccc}
\hline Usia & $\mathbf{n}$ & $\mathbf{\%}$ \\
\hline $18-24$ & 7 & 16,2 \\
$25-30$ & 9 & 21 \\
$31-35$ & 8 & 18,6 \\
$36-40$ & 6 & 14 \\
$41-45$ & 7 & 16,2 \\
$46-50$ & 4 & 9,3 \\
$51-55$ & 2 & 4,7 \\
Total & $\mathbf{4 3}$ & $\mathbf{1 0 0}$ \\
\hline
\end{tabular}

Pada kategori pekerjaan, didapatkan yang paling banyak ialah ibu rumah tangga sebanyak 13 orang $(30,2 \%)$ dan yang 
paling sedikit ialah tukang batu, buruh tani dan sopir dengan jumlah masing-masing 1 orang $(2,3 \%)$ (Tabel 3).

Tabel 3. Distribusi Responden Menurut Pekerjaan

\begin{tabular}{ccc}
\hline Pekerjaan & n & \% \\
\hline Pelajar/Mahasiswa & 10 & 23,3 \\
Buruh harian lepas & 7 & 16,2 \\
Ibu rumah tangga & 13 & 30,2 \\
Karyawan swasta & 5 & 11,7 \\
Tukang kayu & 2 & 4,7 \\
Tukang batu & 1 & 2,3 \\
Buruh tani & 1 & 2,3 \\
Sopir & 1 & 2,3 \\
Belum/Tidak bekerja & 3 & 7 \\
Total & 43 & 100
\end{tabular}

Berdasarkan hasil penelitian untuk tingkat kecemasan, didapatkan bahwa responden terbanyak mengalami kecemasan ialah pada kecemasan sedang berjumlah 22 orang $(51,1 \%)$, diikuti oleh kecemasan ringan berjumlah 11 orang $(25,6 \%)$, dan kecemasan berat berjumlah 8 orang $(18,6 \%)$, sedangkan yang tidak mengalami kecemasan berjumlah 2 orang $(4,7 \%)$ (Tabel 4).

Tabel 4. Distribusi responden menurut tingkat kecemasan (HAR-S)

\begin{tabular}{ccc}
\hline Tingkat & $(\mathrm{n})$ & $\%$ \\
Kecemasan & & \\
\hline Ringan & 11 & 25,6 \\
Sedang & 22 & 51,1 \\
Berat & 8 & 18,6 \\
Tidak ada & 2 & 4,7 \\
Total & 43 & 100 \\
\hline
\end{tabular}

\section{BAHASAN}

Berdasarkan hasil penelitian yang telah dilakukan terhadap 43 responden, didapatkan bahwa kategori jenis kelamin terbanyak adalah perempuan berjumlah 22 orang $(51,1 \%) ; 5$ orang di antaranya mengalami kecemasan berat. Perempuan lebih mudah megalami kecemasan karena perempuan lebih sensitif sedangkan laki-laki lebih eksploratif. Penelitian dari Bastia dan $\operatorname{Kar}^{6}$ juga Burke JD et al. mendapatkan bahwa perempuan lebih banyak mengalami depresi dan juga kecemasan, tetapi hasilnya tidak terlalu bermakna. ${ }^{6}$ Secara umum, perempuan telah diberikan peran sebagai caregiver yaitu peran yang dapat menyebabkan peningkatan tingkat stres setelah terjadinya bencana. Sebagai caregiver, perempuan bisa mengalami ketidakseimbangan dalam merawat anak-anak dan rumah tangganya sehingga terjadinya peningkatan stres dan kecemasan.

Pada kategori usia, responden terbanyak berusia 25-30 tahun yang berjumlah 9 orang (21\%); 4 orang mengalami kecemasan ringan dan 3 orang mengalami kecemasan berat. Feist ${ }^{7}$ menyatakan bahwa semakin bertambahnya usia, semakin matang pula kondisi psikologi individu, sehingga semakin baik pula beradaptasi terhadap kecemasan. Kecemasan juga lebih sering dialami oleh usia muda karena kurangnya pengetahuan dan pengalaman yang dimiliki oleh orang tua. Pengetahuan dan pengalaman yang banyak menyebabkan seseorang akan lebih siap dalam menghadapi sesuatu. ${ }^{7}$ Penelitian yang dilakukan oleh Rafiey et al. ${ }^{8}$ juga mendapatkan hasil bahwa orang muda lebih mudah mendapatkan gangguan psikologis daripada orang tua. Biasanya, pada orang muda, hal yang paling dikhawatirkan ialah tentang masa depannya. Sebuah penelitian melaporkan bahwa kekhawatiran akan uang merupakan penyebab terbesar dari stres dan kecemasan orang muda diikuti oleh ketakutan tentang masa depannya seperti dapat mencapai keseimbangan kerja dan kehidupan.

Pada kategori pekerjaan, responden terbanyak ialah ibu rumah tangga berjumlah 13 orang $(30,2 \%)$; 5 orang mengalami kecemasan sedang dan 3 orang mengalami kecemasan berat. Ibu rumah tangga adalah seorang wanita yang tidak bekerja di luar rumah dan pekerjaan utamanya ialah menjalankan dan mengelola rumah tangganya seperti merawat anak-anak, memasak, membeli barang yang dibutuhkan keluarga. Seorang ibu rumah tangga bertanggung jawab atas rumah tangganya. ${ }^{9}$ Ibu rumah tangga dapat mengalami kecemasan karena mereka bertanggung jawab untuk merawat 
anggota keluarga dan menempatkan kebutuhan keluarga mendahului kebutuhan mereka sendiri. ${ }^{10}$

\section{SIMPULAN}

Berdasarkan hasil penelitian ini dapat disimpulkan bahwa sebagian besar masyarakat yang berdiam di daerah rawan longsor Ranomut Manado mengalami kecemasan, terutama kecemasan sedang.

\section{SARAN}

Untuk keamanan warga, dapat disediakan sarana prasarana yang dibutuhkan sehingga warga tidak terus merasa ketakutan dan cemas berkepanjangan. Diharapkan para warga untuk tetap berwaspada, dan juga warga bisa mengontrol diri dalam menghadapi suatu bencana.

Untuk penelitian selanjutnya, dapat disempurnakan dengan mengkaji lebih lanjut terkait faktor penyebab kecemasan yang dialami.

\section{DAFTAR PUSTAKA}

1. Badan Nasional Penanggulangan Bencana. Definisi dan jenis bencana. Available from: https://www.bnpb.go.id/home/ definisi

2. Faizana F, Nugraha AL, Yuwono BD. Pemetaan risiko bencana tanah longsor Kota Semarang. J Geod Undip. 2015;4(1): 2337-45.

3. Lateh H, Ahmad J, Mohamad NA. The prevalence of posttraumatic stress disorder among landslide victims. J Psychol Clin Psychiatry. 2010;9(2): 160-7.

4. Pamina A, Mbbs M. What is anxiety? Anxiety. 1999:1-6.

5. Medical News Today. Anxiety: causes, symptoms, and treatments. Available from: https://www.medicalnewstoday.com/info/ anxiety.

6. Kar N, Bastia BK. Post-traumatic stress disorder, depression and generalised anxiety disorder in adolescents after a natural disaster: a study of comorbidity. 2006.Available from:https: //www. ncbi.nlm.nih.gov/pmc/articles/PMC1563 462/

7. Elias Y. Faktor-faktor yang mempengaruhi tingkat kecemasan keluarga di ruang high care unit (HCU) Rumah Sakit Immanuel Bandung. Available from: http://ejournal. stik-immanuel.ac.id/file.php?file= prosiding \&id $=494 \& \mathrm{~cd}=\mathrm{d} 51 \mathrm{adb} 1 \mathrm{~b} 462 \mathrm{a} 14$ 1252e1959385771aad\&name $=435$ 454\%20Yuliana\%20Elias.pdf

8. Rafiey H, Momtaz YA, Alipour F, Khankeh H, Ahmadi S, Khoshnami MS, et al. Are older people more vulnerable to long-term impacts of disasters? 2016. Available from: https://www.ncbi.nlm. nih. gov/pmc/articles/PMC5153288/

9. Macmillian dictionary. Housewife. Available from: https://www.macmillandictionary. com/dictionary/american/housewife

10. World Health Organization. Gender and health in disasters. 2002. Available from: http://www.who.int/gender/other_health/ genderdisasters.pdf 